\title{
Antinuclear Antibodies and Clinical Associations in a British Cohort with Limited Cutaneous Systemic Sclerosis
}

\author{
ANGELA E. GLIDDON, CAROLINE J. DORÉ, JULIET DUNPHY, ZOË BETTERIDGE, NEIL J. McHUGH, \\ PETER J. MADDISON, and the QUINS Trial Study Group
}

\begin{abstract}
Objective. To assess the prevalence of disease-specific autoantibodies in patients with limited cutaneous systemic sclerosis (lcSSc).

Methods. Sera from 180 patients with lcSSc were analyzed for antinuclear antibody (ANA). Clinical characteristics were compared in the presence or absence of specific autoantibodies.

Results. SSc-specific antibodies were detected in 135 patients (75\%). Associations were found between anticentromere antibody and age at lcSSc diagnosis, telangiectasia, reduced creatinine clearance, and selective reduction in DLCO, and between antitopoisomerase-I and pulmonary fibrosis.

Conclusion. The majority of patients with lcSSc belong to distinctive serologic subsets, potentially with prognostic significance. (First Release Jan 15 2011; J Rheumatol 2011;38:702-5; doi:10.3899/ jrheum.100754)
\end{abstract}

\section{Key Indexing Terms:}

\section{SCLERODERMA LIMITED CUTANEOUS SYSTEMIC SCLEROSIS AUTOANTIBODIES}

Systemic sclerosis (SSc) is characterized by disease-specific antinuclear antibodies (ANA) that help identify disease subsets ${ }^{1}$. We studied whether previously reported associations with hallmark ANA held true in a more tightly defined cohort of patients with limited cutaneous SSc (lcSSc).

\section{MATERIALS AND METHODS}

A total of 180 patients fulfilling the criteria for $1 \mathrm{cSSc}^{2}$ were recruited from 20 UK centers for the QUINS trial (ISRCTN 57984704) $)^{3}$. The study was approved by the Multicentre Research Ethics Committee (MREC Wales 00/09/19); all patients provided written informed consent.

The patients were recruited between March 2001 and February 2004 and followed prospectively for up to 3 years. Clinical and serological data were obtained as in Gliddon, $e t a l^{3}$.

Serum samples taken at the baseline QUINS Trial visit were sent to a central laboratory for analysis of ANA and antinucleolar antibodies (ANoA). They were initially screened using indirect immunofluorescence (IIF) on Hep-2 cells using a serum dilution of $1 / 40$ and polyvalent FITC-conjugated secondary antibody. IIF patterns were interpreted by 2 independent, experienced observers. Positive samples were then further

From Bangor University, Bangor; the MRC Clinical Trials Unit, London; BIRD Diagnostics, Bath; and the RACE Unit, Royal National Hospital for Rheumatic Diseases, Bath, UK.

Funded by Arthritis Research UK.

A.E. Gliddon, DPhil, MA, Clinical Trial Coordinator, Bangor University; C.J. Doré, BSc, Senior Statistician, MRC Clinical Trials Unit; J. Dunphy, BA, AIBMS, Clinical Scientist, BIRD Diagnostics; Z. Betteridge, PhD, Research Scientist, BIRD Diagnostics; N.J. McHugh, MD, Consultant Rheumatologist, RACE Unit, Royal National Hospital for Rheumatic Diseases; P.J. Maddison, MD, Professor of Musculoskeletal Medicine, Bangor University.

Address correspondence to Prof. P. Maddison, School of Medical

Sciences, Brigantia Building, Bangor LL57 2AS, UK.

E-mail:p.maddison@bangor.ac.uk

Accepted for publication November 26, 2010. investigated for their autoantibody specificity. Ouchterlony immunodiffusion was performed using a commercial antigen source (Bio-Diagnostics, Upton-upon-Severn, UK) and rabbit thymus extract (Pel-Freez; Rogers, AR, USA). Commercial ELISA (The Binding Site, Birmingham, UK) were used for confirmatory purposes for anti-U1-RNP, anti-Sm, anti-Ro, anti-La, and antitopoisomerase I (anti-topo I). Protein or RNA immunoprecipitation of K562 cells was used to detect anti-RNA polymerase antibodies and other ANoA such as anti-PM-Scl, anti-U3-RNP, and anti-Th/To, as described in Betteridge, et $a l^{4}$.

Clinical characteristics were compared in the presence or absence of the 4 most common ANA. Fisher's exact test was used for categorical variables, $t$ test or Mann-Whitney $U$ test for continuous variables, and multiple regression to correct creatinine clearance for age.

\section{RESULTS}

All 180 patients [mean age 55 yrs (range 21-82), 154 women] were white except for 3 Asians, 2 African Caribbeans, and 2 people of mixed race. The median duration of Raynaud's phenomenon (RP) was 10.7 years (range $<1$ to $65 \mathrm{yrs}$ ) and median disease duration from fulfilling $\mathrm{SSc}$ criteria was 4 years (range $<1$ to $46 \mathrm{yrs}$ ). The median number of organ systems affected by lcSSc was 3 (range 1 to 7). The median skin score was 5 (range 0 to 23 ).

ANA were detected by IIF in $96 \%$ of subjects. SSc-specific antibodies were identified in $75 \%$, with the most frequent being anticentromere antibody (ACA; Table 1). Mostly, these antibodies were mutually exclusive (1 patient with ACA had anti-topo I and 1 patient with ACA had anti-PM-Scl). A further $10 \%$ had anti-U1-RNP or anti-Ro and/or anti-La, antibody specificities recognized as markers of connective tissue diseases but with less specificity for SSc. In $12 \%$, the autoantibody specificity could not be identified.

Clinical associations are summarized in Tables 2 and 3.

Personal non-commercial use only. The Journal of Rheumatology Copyright @ 2011 . All rights reserved. 
Table 1. Frequencies of antinuclear antibodies (ANA).

\begin{tabular}{lc}
\hline ANA Type & No. Patients (\%) \\
\hline Systemic sclerosis-specific ANA & \\
Anticentromere antibody & $91(51)$ \\
Antitopoisomerase I & $16(9)$ \\
Anti-Th/To RNP & $14(8)$ \\
Anti-PM-Scl & $6(3)$ \\
Anti-RNA pol I, II, III (one I, III only) & $5(3)$ \\
Anti-U3 RNP & $3(2)$ \\
Connective tissue disease-associated ANA & \\
Anti-U1 RNP & $15(8)$ \\
Anti-Ro and/or anti-La & $3(2)$ \\
Other & $22(12)$ \\
Unidentified ANA & $7(4)$ \\
Negative & \\
\hline
\end{tabular}

Patients who were ACA-positive were significantly older at diagnosis, while anti-U1-RNP-positive patients were significantly younger. Age of onset and frequency and severity of RP were not significantly different in any of the serological groups (data not shown). Skin score was higher in anti-topo I-positive patients and less in ACA-positive patients. A direct comparison (Mann-Whitney $U$ test) of skin score in ACA and anti-topo I patients showed a significant difference $(\mathrm{p}=0.017)$. ACA positivity was associated with telangiectasia (OR 2.4, 95\% CI 1.3-4.3) but the median number of organ systems affected, calcinosis, and levels of hemoglobin, creatinine, and proteinuria showed no association with ANA subtype. However, creatinine clearance was signifi- cantly reduced in patients with ACA. The proportion of ACA-positive patients with an isolated reduction of DLCO, assessed by ratio of forced vital capacity (FVC)/DLCO of $>1.4$ (OR 1.9, 95\% CI 1.05-3.6) was significantly higher than in non-ACA patients. The percentage of ACA-positive patients with pulmonary artery pressure $>30 \mathrm{~mm} \mathrm{Hg}$ by transthoracic echocardiography was higher (but not significantly so) than that of ACA-negative patients. Of the 13 patients who had high estimated pulmonary artery pressure, 8 had ACA, 4 had unidentifiable ANA, and 1 had anti-U3-RNP antibody. Anti-topo I was associated with lung fibrosis (OR 6.0, 95\% CI 1.9-18.7).

\section{DISCUSSION}

In this predominantly white population of patients with lcSSc, drawn from multiple centers across England and Wales, ACA was the predominant autoantibody specificity, occurring in a proportion of patients similar to previous reports ${ }^{5}$. Therefore, serologically, this was a heterogeneous population in which mostly there was mutual exclusiveness of SSc-specific autoantibodies.

Autoantibodies considered more commonly associated with diffuse cutaneous SSc, such as anti-topo I, anti-RNA polymerase antibodies, and anti-U3-RNP, were found in $14 \%$. However, the relationship between these autoantibodies and the extent and rapidity of skin involvement is not absolute, and at least 1 other study has reported that over $30 \%$ of patients positive for anti-topo I had $1 \mathrm{cSSc}$.

Similar to other reports ${ }^{7}$, patients who were ACA-posi-

Table 2. Associations of antinuclear antibodies (ANA) with continuous variables. Differences for which 95\% CI do not overlap zero, and are therefore significant $(\mathrm{p}<0.05)$, are shown in bold type. For $\mathrm{t}$ tests and multiple regression analysis, the difference between the mean for patients with each ANA and the mean for all patients without that ANA is shown. For Mann-Whitney U tests, the difference between median values for patients with each ANA and for all patients without that ANA is given.

\begin{tabular}{|c|c|c|c|c|}
\hline Criteria & $\begin{array}{c}\text { Difference } \\
\text { Between ACA } \\
(\mathrm{n}=91) \text { and } \\
\text { not ACA } \\
(95 \% \mathrm{CI})\end{array}$ & $\begin{array}{c}\text { Difference } \\
\text { Between Anti-topo I } \\
(\mathrm{n}=16) \text { and } \\
\text { Not Anti-topo I } \\
(95 \% \mathrm{CI})\end{array}$ & $\begin{array}{c}\text { Difference } \\
\text { Between Anti-RNP } \\
(\mathrm{n}=15) \text { and } \\
\text { not Anti-RNP } \\
(95 \% \mathrm{CI})\end{array}$ & $\begin{array}{c}\text { Difference } \\
\text { Between Anti-Th/To } \\
(\mathrm{n}=14) \text { and } \\
\text { Not Anti-Th/To } \\
(95 \% \mathrm{CI})\end{array}$ \\
\hline $\begin{array}{l}\text { Age at diagnosis of } \\
\text { lcSSc, yrs }\end{array}$ & $\begin{array}{c}4.6 \\
(1.0 \text { to } 8.2)\end{array}$ & $\begin{array}{c}-2.5 \\
(-8.9 \text { to } 3.9)\end{array}$ & $\begin{array}{c}-8.6 \\
(-15.1 \text { to }-2.0)\end{array}$ & $\begin{array}{c}-4.6 \\
(-11.0 \text { to } 1.8)\end{array}$ \\
\hline Skin score* & $\begin{array}{c}-2 \\
(-3 \text { to } 0)\end{array}$ & $\begin{array}{c}2 \\
(0 \text { to } 5)\end{array}$ & $\begin{array}{c}0 \\
\text { (-2 to } 2)\end{array}$ & $\begin{array}{c}0 \\
(-3 \text { to } 1)\end{array}$ \\
\hline Expected FVC, \% & $\begin{array}{c}11.6 \\
\text { (6.7 to } 16.4)\end{array}$ & $\begin{array}{c}-9.1 \\
(-23 \text { to } 5.0)\end{array}$ & $\begin{array}{c}-9.9 \\
(-19.2 \text { to }-0.6)\end{array}$ & $\begin{array}{c}1.1 \\
(-6.4 \text { to } 14.6)\end{array}$ \\
\hline Expected DLCO,\% & $\begin{array}{c}-0.18 \\
(-5.1 \text { to } 4.7)\end{array}$ & $\begin{array}{c}-6.4 \\
(-18 \text { to } 5.6)\end{array}$ & $\begin{array}{c}2.4 \\
(-6.8 \text { to } 11.7)\end{array}$ & $\begin{array}{c}-2.1 \\
(-11.4 \text { to } 7.2)\end{array}$ \\
\hline Expected $\mathrm{KCO}^{*}, \%$ & $\begin{array}{c}-6 \\
(-12 \text { to } 0)\end{array}$ & $\begin{array}{c}6 \\
(-5 \text { to } 15)\end{array}$ & $\begin{array}{c}8 \\
(-3 \text { to } 19)\end{array}$ & $\begin{array}{c}-2 \\
(-14 \text { to } 11)\end{array}$ \\
\hline Creatinine clearance $* *$ & $\begin{array}{c}-12.4 \\
(-21.5 \text { to }-3.3)\end{array}$ & $\begin{array}{c}12.7 \\
(-3.0 \text { to } 28.3)\end{array}$ & $\begin{array}{c}-0.9 \\
(-17.5 \text { to } 15.7)\end{array}$ & $\begin{array}{c}0.8 \\
(-16.0 \text { to } 17.6)\end{array}$ \\
\hline
\end{tabular}

* Difference in medians. ** Adjusted for age. ACA: anticentromere antibodies; lcSSc: limited cutaneous systemic sclerosis; FVC: forced vital capacity; DLCO: diffusing lung capacity for carbon monoxide; KCO: carbon monoxide transfer coefficient corrected for lung volumes. 
Table 3. Associations of antinuclear antibodies (ANA) with categorical variables. All data are percentages. Percentages of patients within each class of ANA who have certain characteristics are given with the probability value from Fisher's exact test that these are the same percentages in the patients without each particular ANA. Comparisons significant at the 0.05 level are in bold type.

\begin{tabular}{|c|c|c|c|c|c|c|c|c|c|c|c|c|}
\hline Criteria & $\mathrm{ACA}$ & Not ACA & $\mathrm{p}$ & Anti-topo I & $\begin{array}{c}\text { Not } \\
\text { Anti-topo I }\end{array}$ & $\mathrm{p}$ & Anti-RNP & $\begin{array}{c}\text { Not } \\
\text { Anti-RNP }\end{array}$ & $\mathrm{p}$ & $\begin{array}{l}\text { Anti- } \\
\text { Th/To }\end{array}$ & $\begin{array}{l}\text { Not Anti- } \\
\text { Th/To }\end{array}$ & $\mathrm{p}$ \\
\hline Telangiectasia & 63 & 42 & $<0.01$ & 56 & 53 & 0.8 & 7 & 57 & $<0.01$ & 64 & 52 & 0.4 \\
\hline Calcinosis & 24 & 15 & 0.13 & 31 & 18 & 0.3 & 0 & 21 & 0.05 & 21 & 19 & 0.7 \\
\hline Arthritis & 29 & 41 & 0.12 & 31 & 35 & 1.0 & 40 & 34 & 0.8 & 50 & 33 & 0.2 \\
\hline Esophageal involvement & 52 & 41 & 0.14 & 50 & 46 & 0.8 & 13 & 49 & 0.01 & 43 & 46 & 1.0 \\
\hline Pulmonary fibrosis & 7 & 17 & 0.04 & 38 & 9 & $<0.01$ & 7 & 12 & 1.0 & 21 & 11 & 0.2 \\
\hline $\mathrm{FVC} / \mathrm{DLCO}>1.4$ & 61 & 45 & 0.05 & 56 & 53 & 0.8 & 42 & 54 & 0.6 & 54 & 53 & 1.0 \\
\hline $\begin{array}{l}\text { Pulmonary artery } \\
\text { pressure }>30 \mathrm{~mm} \mathrm{Hg}\end{array}$ & 9 & 6 & 0.6 & 0 & 8 & 0.6 & 0 & 8 & 0.6 & 8 & 7 & 1.0 \\
\hline
\end{tabular}

ACA: anticentromere antibodies; FVC: forced vital capacity; DLCO: diffusing lung capacity for carbon monoxide.

tive were older at lcSSc diagnosis and, by inference, demonstrated a longer interval between the onset of RP and the development of other SSc features. There was a significant association with telangiectasia, as described by others ${ }^{1,8}$, and reduced creatinine clearance. This result is similar to studies using ${ }^{51} \mathrm{CrEDTA}$ clearance as a measure of renal function ${ }^{9}$. Patients who were ACA-positive also demonstrated selective reduction of DLCO, indicated by an FVC/DLCO ratio $>1.4^{10}$. This ratio may predict isolated pulmonary hypertension, especially if it exceeds $1.8^{11}$. In our patients who were ACA-positive, $9 \%$ had an estimated pulmonary artery pressure $>30 \mathrm{~mm} \mathrm{Hg}$ that was not significantly greater than in the other patients with lcSSc. However, in terms of studying predictors for disease progression, the length of followup was not very long.

Although all patients in our study satisfied criteria for $\mathrm{lcSSc}^{2}$, the skin score in patients with anti-topo I was significantly higher than in those with ACA. Anti-topo I-positive patients had a significantly higher risk of developing pulmonary fibrosis. This supports an observation ${ }^{7}$ that the association between anti-topo I and pulmonary involvement occurs irrespective of the extent of skin involvement and consequently, disease classification. The presence of anti-To/Th has also been reported to identify patients with $1 \mathrm{CSSc}$ at risk of pulmonary fibrosis ${ }^{12}$ and with a worse prognosis ${ }^{13}$. However, clinical correlations were not found in this study and only 1 of 14 patients with anti-To/Th RNP had pulmonary fibrosis.

Our study shows that most patients with lcSSc fall into distinct serologic subsets. Since these autoantibodies are a very early feature, persisting throughout the course of the disease $^{14}$, ANA identification is important for predicting $\mathrm{SSc}$ in patients presenting with, for example, RP. Additionally, individual antibodies have been associated with a particular constellation of clinical features and potentially have prognostic significance.

\section{ACKNOWLEDGMENT}

We acknowledge the staff at QUINS Trial participating hospitals.

\section{APPENDIX}

List of study collaborators. The QUINS Trial Study Group, in alphabetical order: T. Barnes, University Hospital Aintree; C. Black, Royal Free Hospital, London; A. Borg, Nevill Hall Hospital, Gwent; J. Camilleri, University Hospital, Cardiff; K. Chakravarty, Harold Wood Hospital, Romford; C. Denton, Royal Free Hospital, London; P. Emery, Chapel Allerton Hospital, Leeds; B. Griffiths, Freeman Hospital, Newcastle; A. Herrick, Hope Hospital, Salford; N. Hopkinson, Christchurch Hospital, Christchurch; P. Hickling, Derriford Hospital, Plymouth; P. Lanyon, Queen's Medical Centre, Nottingham; C. Laversuch, Taunton and Somerset Hospital, Taunton; T. Lawson, Princess of Wales Hospital, Bridgend; R. Mallya, Halton General Hospital, Runcorn; R. Moots, University Hospital, Aintree; M. Nisar, Queen's Hospital, Burton-upon-Trent; C. Rhys-Dillon, Royal Glamorgan Hospital, Llantrisant; T. Sheeran, Cannock Chase Hospital, Cannock.

\section{REFERENCES}

1. Steen VD. Autoantibodies in systemic sclerosis. Semin Arthritis Rheum 2005;35:35-42.

2. LeRoy EC, Black C, Fleischmajer R, Jablonska S, Krieg T, Medsger TA Jr, et al. Scleroderma (systemic sclerosis): classification, subsets and pathogenesis. J Rheumatol 1988; $31: 202-5$

3. Gliddon AE, Doré CJ, Black CM, McHugh N, Moots R, Denton $\mathrm{CP}$, et al. Prevention of vascular damage in scleroderma and autoimmune Raynaud's phenomenon: A multicentre randomized, double-blind, placebo-controlled trial of the angiotensin-converting enzyme inhibitor quinapril. Arthritis Rheum 2007;56:3837-46.

4. Betteridge Z, Gunawardena H, North J, Slinn J, McHugh N. Identification of a novel autoantibody directed against small ubiquitin-like modifier activating enzyme in dermatomyositis. Arthritis Rheum 2007;56:3132-7.

5. Spencer-Green G, Alter D, Welch HG. Test performance in systemic sclerosis: anti-centromere and anti-Scl-70 antibodies. Am J Med 1997;103:242-8.

6. Kuwana M, Kaburaki J, Okano Y, Tojo T, Homma M. Clinical and prognostic associations based on serum antinuclear antibodies in Japanese patients with systemic sclerosis. Arthritis Rheum 1994;37:75-83.

7. Walker UA, Tyndall A, Czirjak L, Denton C, Farge-Bancel D, Kowal-Bielecka O, et al. Clinical risk assessment of organ manifestations in systemic sclerosis: a report from the EULAR Scleroderma Trials and Research Group database. Ann Rheum Dis 2007;66:754-63.

8. Walker JG, Fritzler MJ. Update on autoantibodies in systemic sclerosis. Curr Opin Rheumatol 2007;19:80-91. 
9. Hesselstrand R, Scheja A, Shen GQ, Wiik A, Akesson A. The association of antinuclear antibodies with organ involvement and survival in systemic sclerosis. Rheumatology 2003;42:534-40.

10. Steen VD, Graham G, Conte C, Owens G, Medsger TA Jr. Isolated diffusing capacity reduction in systemic sclerosis. Arthritis Rheum 1992;35:765-70.

11. Steen V, Medsger TA Jr. Predictors of isolated pulmonary hypertension in patients with systemic sclerosis and limited cutaneous involvement. Arthritis Rheum 2003;48:516-22.

12. Ceribelli A, Cavazzana I, Franceschini F, Airo P, Tincani A, Cattaneo R, et al. Anti-Th/To are common antinucleolar autoantibodies in Italian patients with scleroderma. J Rheumatol 2010;37:2071-5.

13. Mitri GM, Lucas M, Fertig N, Steen VD, Medsger TA Jr. A comparison between anti-Th/To- and anticentromere antibody-positive systemic sclerosis patients with limited cutaneous involvement. Arthritis Rheum 2003;48:203-9.

14. Tramposch HD, Smith CD, Senecal JL, Rothfield N. A long-term longitudinal study of anticentromere antibodies. Arthitis Rheum 1984;27:121-4. 